\title{
Recovery of Fibroblast-Like Cells after 160 Days of Postmortem Storage of Goat Skin Tissues in Refrigerated Media
}

\section{Hadj S Aoued and Mahipal Singh*}

Animal Biotechnology Laboratory, Agricultural Research Station, Fort Valley State University, Fort Valley, GA 31030, USA

\begin{abstract}
Animals have been cloned from frozen decade old postmortem tissues preserved within few hours of animal death. Delay in tissue preservation may reduce cloning success due to compromised nuclear DNA integrity. In vitro culture of cells ensures nuclear integrity and is a preferred method of preparing somatic cells for cloning. However, the time limits of postmortem recovery of cells capable of in vitro culture are not precisely known. Here we show recovery of fibroblast-like cells after 160 days of postmortem storage of goat skin in culture media at $4^{\circ} \mathrm{C}$. Forty skin explants were cultured at 10 days interval up to 160 days and the outgrowing fibroblast-like cells around them were observed under inverted microscope. Explants with a cluster of more than 50 cells, after 10-12 days of culture initiation, were considered positive. We observed the outgrowth in all the time points, however, the confluence level reduced with increasing postmortem time interval. Secondary cultures established from primary outgrowth of 0-, 90and 160-dpm tissues exhibited similar fibroblast-like morphology. Growth curves of 0 - and 90 -dpm cells were similar but $160-\mathrm{dpm}$ cells grow slightly slower. Cytogenetic analysis performed on twenty G-banded metaphase cells of 160-dpm cell line revealed an apparently normal male goat karyotype with 60 chromosomes and their post-freezing cell-viability was $>67 \%$. Potential of using these cells to clone the goats remains to be seen in future. These findings may be useful in decisions for preservation of tissues for future cloning of animals and cell therapy.
\end{abstract}

Keywords: Goat skin; Fibroblast outgrowth; Explants; Postmortem; Cryopreservation; Animal cloning; Cell therapy

\section{Introduction}

One of the important challenges that come along with the high demographic growth is the decrease in diversity of livestock and poultry genetic resources. Therefore, preservation of tissues from various species/breeds or animals with desired traits has been suggested to conserve genetic diversity, before it is too late $[1,2]$. These preserved genetic resources could be utilized globally to overcome the climatic and/or other challenges to meet the increasing global demand for food, especially the protein sources. Some of the practical options for conservation are the preservation of semen, ovarian tissues, embryos, genomic and cDNA libraries [3]. However, preservation of small tissue samples, or cells cultured from them, seems to be ideal after the success of somatic cell nuclear transfer (SCNT) aka cloning technique. SCNT was developed first in Scotland [4] and subsequently practiced in many laboratories to clone almost every livestock species [5].

Different types of somatic cells have been used successfully to perform SCNT in mammals [2,6-8]. However, fibroblasts are the most commonly used cells because these cells are characterized as unspecialized mesenchymal cells with a high proliferation potential and their ability to differentiate into a variety of other connectives tissues, such as bone, cartilage, and muscle [9]. In order to obtain a healthy clone with full term development, the integrity of the nuclear genome of donor cells is essential [10]. It has been shown that cells that have a normal behavior in culture including their viability, proliferation rate, and longevity ensure the genomic integrity and enhance the success rate of animal cloning [11]. Recent studies have shown that the postmortem tissues can be preserved for many years at sub-zero temperatures before producing live animals by SCNT [12]. However, these tissues are preserved within few hours or days of animal death. Sometimes, it is not possible at farm level or even desired, for example, cloning of superior meat animals is possible only after post slaughter carcass evaluation (for meat quality) of animal herd. Delay in tissue preservation from slaughtered animals reduces success rate due to inability of retrieving live cells and/or intact nuclear DNA for cloning [10]. In vitro culture of cells is one way of ensuring nuclear integrity [11]. In vitro culture of cells from live as well as dead animal tissues preserved at sub-zero temperatures has been reported in several studies $[10,13-16]$. The nucleus from these cultured cells has been used to clone the animals even after many years of their death $[10,15]$.

There is not enough literature to show as for how long the live and culturable cells can be recovered from postmortem tissues in mammalian species. There are reports of successful autograft skin transplantation up to 140 days and allograft transplantation up to 185 days of skin storage in refrigerated media [17]. However, since structural integrity and viability of refrigerated skin does not survive so long, it was suggested that these reports represent repopulation of cells from recipient in the lattices of grafts [17]. Fibroblast cells in postmortem skin tissues stored at $4^{\circ} \mathrm{C}$ were cultured up to $12-14$ days after animal death in rabbits, pigs, goats and sheep [18,19], up to 41 days postmortem in goats [20], up to 24 days in human foreskin when stored in refrigerated media [21]. Muscle stem cells have been shown to survive for 17 days postmortem in human beings and 16 days in mice [22]. Here we show, recovery of fibroblast-like cells 160 days postmortem from goat skin tissues stored in refrigerated media, and demonstrate that these cells are cytogenetically stable with normal

*Corresponding author: Mahipal Singh, PhD, Associate Professor of Animal Biotechnology, Agricultural Research Station, 1005 State University Drive, Fort Valley State University, Fort Valley, GA 31030, USA, Tel: 478822 7; Fax: 478 8256; E-mail: singhm@fvsu.edu

Received May 30, 2015; Accepted June 08, 2015; Published June 10, 2015

Citation: Aoued HS, Singh M (2015) Recovery of Fibroblast-Like Cells after 160 Days of Postmortem Storage of Goat Skin Tissues in Refrigerated Media. J Veterinar Sci Technol 6: 236. doi:10.4172/2157-7579.1000236

Copyright: (c) 2015 Aoued HS, et al. This is an open-access article distributed under the terms of the Creative Commons Attribution License, which permits unrestricted use, distribution, and reproduction in any medium, provided the original author and source are credited. 
karyotype, were successfully cryopreserved, and exhibit normal growth profile.

\section{Material and Methods}

\section{Sample collection and storage in refrigerated media}

Goat skin samples were procured from the university slaughter house. Ears were excised from the animal head, cleaned with $70 \%$ alcohol swabs and brought to the laboratory in Ziploc bags. Tissues were processed within an hour of collection. About $2.0 \mathrm{~cm}^{2}$ slices of skin were excised from the inner side of the ears using scalpel and a sharp blade. The slices were washed twice in DMEM media containing 50 I.U./mL penicillin and $50 \mu \mathrm{g} / \mathrm{mL}$ streptomycin. The tissue slices were stored in DMEM media with $10 \%$ fetal calf serum in $15 \mathrm{ml}$ tubes in a laboratory refrigerator set at $4^{\circ} \mathrm{C}$ until used for in vitro culture.

\section{Explants preparation and primary cultures}

Skin slices from each tube were cultured, one at a time, after different days of postmortem storage. The excised slices from each tube were chopped into 4-5 $\mathrm{mm} 2$ pieces (explants) and adhered onto two $60 \mathrm{~mm}$ diameter dishes (Falcon, BD Biosciences, Oxnard, CA) for each time point. Each dish contained 5 explants. These explants were cultured in P116 fibroblast culture media (Cell Applications Inc., San Diego, $\mathrm{CA}$ ) at $37^{\circ} \mathrm{C}, 5 \% \mathrm{CO} 2$ in a humidified environment. On Mondays, Wednesdays and Fridays the media was changed and the dishes were observed for any microbial or fungal contamination, explant dislodging, and for outgrowth of fibroblast-like cells under an inverted microscope. Contaminated dishes were removed from the study as soon as observed. On day 10-12 of culture, the presence or absence of the outgrowth around each explant was recorded. Any outgrowth containing a cluster of more than 50 cells was considered positive.

\section{Secondary cultures, cell viability determination and cryopreservation}

Primary outgrowing cells around the explants were trypsinized at $70-90 \%$ confluence and secondary cultures established as described [23]. Briefly, the outgrowing cells in dishes were washed twice with $2.0 \mathrm{~mL}$ of the balanced salt solution without calcium and magnesium (Gibco, Carlsbad, CA) and incubated with $2.0 \mathrm{~mL}$ of $0.125 \%$ trypsin for $5-7 \mathrm{~min}$ at $37^{\circ} \mathrm{C}$. The trypsinized cells were neutralized with $5 \mathrm{vol}$. of P116 complete growth media, counted to assess cell viability using Trypan Blue Dye Exclusion Method [24], and pelleted at $200 \mathrm{x} \mathrm{g}$ for 7 $\mathrm{min}$. The cells were re-suspended in Synth-a-Freeze ${ }^{\star}$ (Life Technologies Corp., Carlsbad, CA) media, aliquoted into cryogenic storage vials $(1.0 \times 105$ cells/vial $)$ and frozen at $-80^{\circ} \mathrm{C}$ o/n using Nalgene ${ }^{\text {tx }}$ Cryo $1^{\circ} \mathrm{C}$ Freezing Container (Nalgene, Rochester, NY). Next day the vials were transferred to liquid nitrogen tank and stored till used for further experiments. Representative cryovials were thawed and the postfreezing cell-viability percentages determined. To establish secondary cultures and/or to expand cell cultures, the frozen vials were quickly thawed at $37^{\circ} \mathrm{C}$, mixed slowly with 10 vol. of the media, pelleted at 200 $\mathrm{x} \mathrm{g}$ for $7 \mathrm{~min}$, dissolved in complete growth media, and cultured in appropriate (T25 or T75) culture flasks.

\section{Determination of growth pattern}

The growth curves were generated from passage 4 cultures of 0 -dpm (0-day postmortem), 90-dpm, and 160-dpm tissue derived celllines, using a 24-well micro titer plate format, as described earlier [25]. Briefly, 20,000 cells per well were inoculated in $0.5 \mathrm{~mL}$ of growth media to initiate the culture. Triplicate wells were trypsinized after 2, 4, 7, 9, 11,14 and 16 days of culture. The viable cells were counted in each well using a Countess ${ }^{\mathrm{na}}$ Automated Cell Counter (Life Technologies Inc.). Mean \pm standard error of the means (SEM) of cell counts $/ \mathrm{mL}$ in triplicate were plotted against time to generate growth curves using Microsoft Excel program.

\section{Cytogenetic analysis}

Cell cultures from 160-dpm cell line at p3 level were analyzed for cytogenetic stability using previously established methodologies [26] at Cell Line Genetics (Madison, WI; www.clgenetics.com). GTL banding technique was used. Chromosome assignments were made as per the Atlas of Mammalian Cytogenetics [27]. Cytogenetic analysis was performed at least on $20 \mathrm{G}$-banded metaphase cells.

\section{Results}

\section{Effect of postmortem time interval on in vitro culture of cells from tissues stored in refrigerated media}

In order to determine the postmortem time-limits, within which live cells can be cultured from tissues stored in refrigerated media, we analyzed 393 skin explants from 4 different goats for in vitro culture. Forty skin explants were cultured after $0,10,20,30,40,50,60,70,80,90$, $100,110,120,130,140,150$ and 160 days of postmortem tissue storage for each time point. The outgrowing cells around the explants were allowed to grow until the confluence was reached at around $70-90 \%$. Subsequently, the dishes were trypsinized to recover the primary cells and stored in liquid nitrogen till used for further analysis. To compare the primary outgrowth around the tissues of various time points, we recorded the data for presence or absence of cell outgrowth on day 10 12 of culture (Table 1). Explants exhibiting clusters of $>50$ cells around them were considered positive. Outgrowth of fibroblast-like cells was visible as early as day 4 of culture in controls $(0-\mathrm{dpm}$, fresh tissue

\begin{tabular}{|c|c|c|c|c|c|c|}
\hline \multirow{2}{*}{$\begin{array}{c}\text { Days } \\
\text { postmortem } \\
\text { interval }\end{array}$} & \multicolumn{5}{|c|}{ \# of outgrowth positive / total explants adhered } & \multirow[b]{2}{*}{ \%outgrowth } \\
\hline & $\begin{array}{c}\text { Goat } 1 \\
\text { ID:5025 }\end{array}$ & $\begin{array}{c}\text { Goat } 2 \\
\text { ID:1614 }\end{array}$ & $\begin{array}{c}\text { Goat } 3 \\
\text { ID:1629 }\end{array}$ & $\begin{array}{c}\text { Goat } 4 \\
\text { ID:1636 }\end{array}$ & Total & \\
\hline 00 & $10 / 10$ & $10 / 10$ & $10 / 10$ & $10 / 10$ & $40 / 40$ & 100 \\
\hline 10 & 06/06 & $10 / 10$ & 09/09 & 09/09 & $34 / 34$ & 100 \\
\hline 20 & $10 / 10$ & 09/09 & $10 / 10$ & 08/08 & $37 / 37$ & 100 \\
\hline 30 & $10 / 10$ & 09/09 & 09/09 & $08 / 08$ & $36 / 36$ & 100 \\
\hline 40 & $10 / 10$ & 09/09 & $10 / 10$ & 05/05 & $34 / 34$ & 100 \\
\hline 50 & $10 / 10$ & $10 / 10$ & 05/05 & $08 / 10$ & $33 / 35$ & 94 \\
\hline 60 & $10 / 10$ & 09/09 & $10 / 10$ & $05 / 05$ & $34 / 34$ & 100 \\
\hline 70 & 09/09 & $10 / 10$ & $10 / 10$ & $10 / 10$ & $39 / 39$ & 100 \\
\hline 80 & * & $10 / 10$ & $10 / 10$ & 05/05 & $25 / 25$ & 100 \\
\hline 90 & $10 / 10$ & $10 / 10$ & * & * & $20 / 20$ & 100 \\
\hline 100 & $n / d$ & 09/09 & * & * & 09/09 & 100 \\
\hline 110 & $n / d$ & $10 / 10$ & * & * & $10 / 10$ & 100 \\
\hline 120 & $n / d$ & $04 / 10$ & * & * & $04 / 10$ & 40 \\
\hline 130 & $n / d$ & 03/05 & * & * & $03 / 05$ & 60 \\
\hline 140 & $n / d$ & $n / d$ & * & 05/05 & $05 / 05$ & 100 \\
\hline 150 & $n / d$ & $n / d$ & $\mathrm{n} / \mathrm{d}$ & $10 / 10$ & $10 / 10$ & 100 \\
\hline 160 & $\mathrm{n} / \mathrm{d}$ & $\mathrm{n} / \mathrm{d}$ & $\mathrm{n} / \mathrm{d}$ & $10 / 10$ & $10 / 10$ & 100 \\
\hline Total & $85 / 85$ & $122 / 130$ & $83 / 83$ & $83 / 95$ & $383 / 393$ & 97.46 \\
\hline
\end{tabular}

Note: $n / d$, not done; "Both dishes were fungal contaminated during culture and thus removed from the study; ${ }^{\$}$ In our experience we never observed outgrowth around tissues that did not adhere to the dish surface.

Table 1: Outgrowth of fibroblast-like cells around skin explants after different days of postmortem storage in refrigerated media. 
derived cells) but increased slightly with increasing postmortem time interval. However, the outgrowth was visible around tissues within first 10-12 days of culture in all the time points studied. Out of 393 explants that adhered to dish surface (for at least first 3 days of culture), 383 (97.46\%) exhibited fibroblast-like cell outgrowth. Table 1 summarizes the in vitro culture results obtained from 4 different goats for various postmortem tissue storage time intervals. As can be seen in Table 1, the outgrowth of cells was observed even after 160 days of postmortem tissue storage, at least in one goat.

\section{Effect of postmortem tissue storage time interval on confluence of primary outgrowth}

We compared confluence level of outgrowth, reached on day 10-12 of culture, for different postmortem tissue storage time intervals. As can be seen in a representative Figure 1, the confluence of outgrowing cells near explants was observed to be in decreasing order with increased postmortem storage time interval. For example, the explants cultured prior to storage (i.e. 0 -dpm) reached to $100 \%$ confluence in about 10 days; while during the same time period about $30 \%$ confluence was reached in 90 -dpm tissues, and about $5 \%$ in 160-dpm tissues (Figure 1). The outgrowth in all the explants studied, including 160-dpm, reached to $70-100 \%$ confluence, however, it took about 5-10 days longer to reach the same level of confluence as that of fresh tissue-derived outgrowth.

Comparative morphology, growth curve, and freezing cellviability of postmortem stored tissue derived cell lines

To determine the differences between cell populations derived from tissues stored for different time points, we established secondary cultures from primary outgrowth of 0 -dpm (control), 90-dpm (middle level) and 160 -dpm (last time point) tissue derived cells by serial passaging as described earlier [28]. Secondary cultures of these cells grow much faster, as compared to the primary outgrowth, and reach $70-90 \%$ confluence in 5-7 days in subsequent passages. As shown in Figure 2, morphology of fibroblast-like cell populations from three celllines look similar i.e. elongated, fibrous and bipolar, which is typical characteristics of fibroblast cells. Their growth curves, although show similarity for 0 - and 90-dpm cell lines, differed slightly from 160-dpm cell line which seems to grow slower (Figure 3 ). To see if the postmortem tissue derived cells can be cryopreserved for future use, without losing their cell-viability significantly, we determined their post-freezing cellviability. As can be seen in Figure 4, we observed $>67 \%$ post-freezing cell-viability in these cell populations.

\section{Cytogenetic stability of postmortem tissue derived cell-line}

To determine any genetic change in the cells cultured from postmortem tissues, a cytogenetic analysis was performed on twenty G-banded metaphase cells of $160-\mathrm{dpm}$ cell-line. We observed a normal male goat karyotype (Figure 5). The diploid number of the chromosomes was 60. It consisted of 58 autosomes and two (X \& Y) sex chromosomes (Figure 5). These results are consistent with earlier studies on goat cytogenetics [29-32]. Twenty metaphase spreads were analyzed for any genetic aberration, of which 19 displayed normal $60 \mathrm{XY}$ chromosomes, while one had a Y chromosome deletion. This aberration was thought to be most likely a technical artifact and thus these results are apparently consistent with a normal male goat karyotype.

\section{Discussion}

Reduction of metabolic activities upon refrigeration is well known and makes the basis of food and organ storage at low temperatures, to increase shelf life. Storage in buffered solutions such as culture media further assists retaining cellular integrity in biological tissues. However, little is known about the time limits of cell survival in mammalian tissues procured postmortem. Knowing as how long the individual cells in postmortem biological tissues remain alive will help design strategies to recover, preserve, and utilize the cells for cell-therapy and cloning of livestock to meet the increasing demand of food especially protein sources in future. In a recent report, fibroblast-like cells were recovered up to 41 days postmortem from goat tissues stored at $4^{\circ} \mathrm{C}$ [20]. These

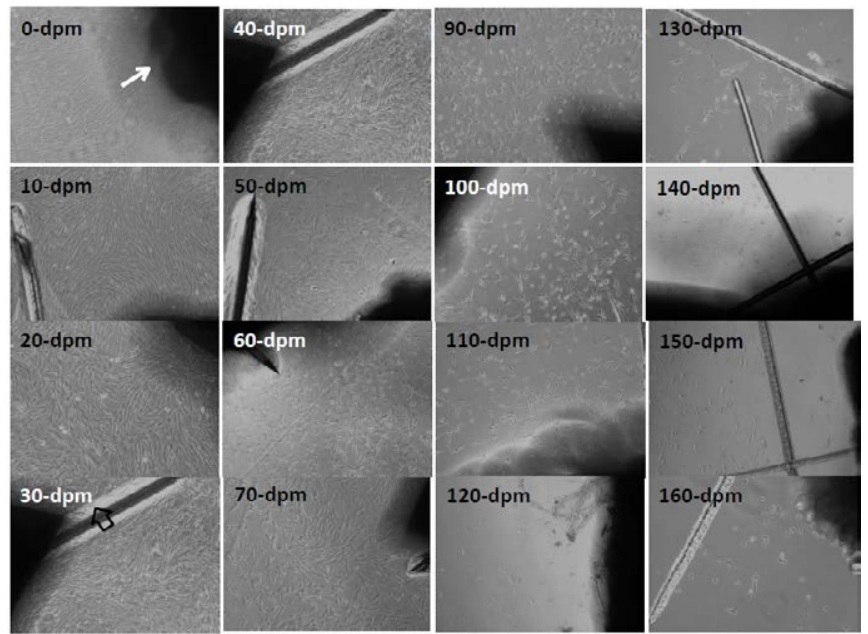

Figure 1: Comparative confluence of primary outgrowing cells on day 1012 of culture for different time points: Skin explants are arrow marked dark shaded areas. Open arrow mark show scratches on dish surface under explants made to facilitate adherence of skin explants. Light microscopy; 100x magnification. dpm, days postmortem.

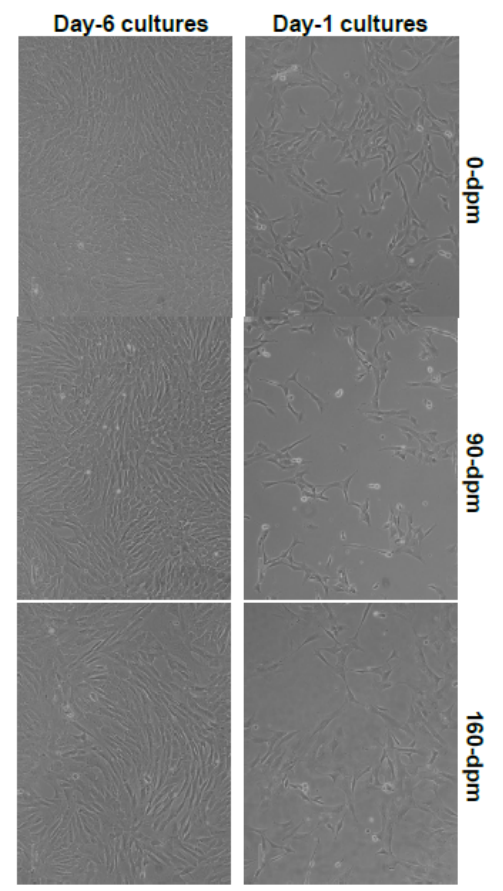

Figure 2: Comparative fibroblast cell morphology of 3 cell lines (passage 4): Light microscopy, x100 magnification. TS100 inverted microscope and DSL2 camera (Nikon) were used to capture images. 


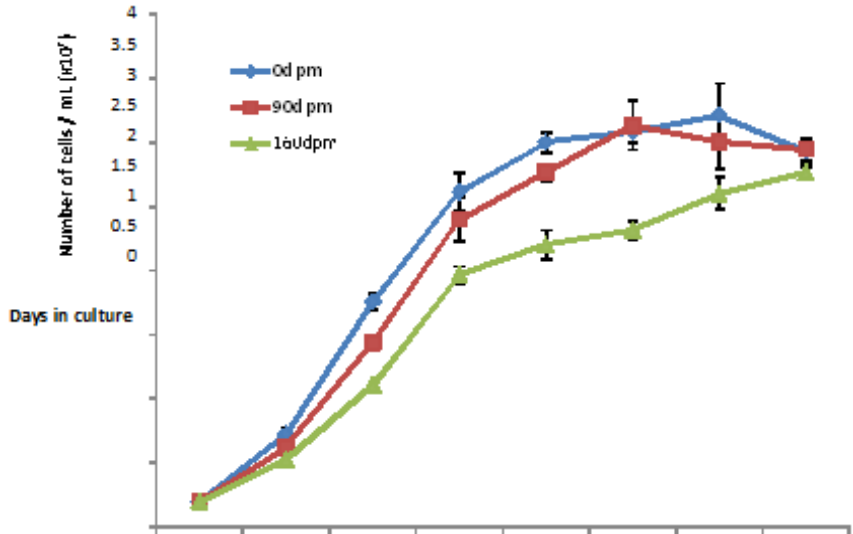

Figure 3: Growth curves of $0-\mathrm{dpm}, 90-\mathrm{dpm}$ and 160-dpm cell-lines, respectively: Each value represents mean \pm SEM of cells in triplicate.

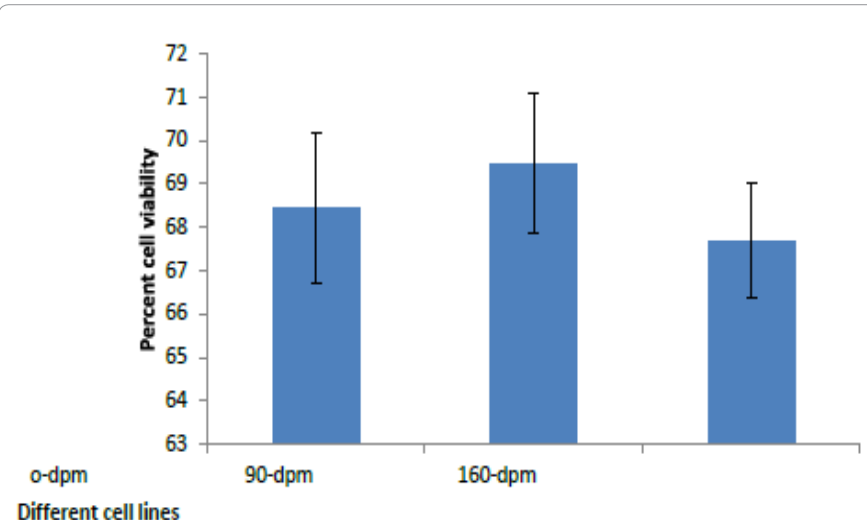

Figure 4: Post-freezing cell-viability estimations: Cell-viability values represent mean SEM of 3 independent experiments for each of the 3 cell lines. results prompted us to ask, if live cells can be recovered even beyond 41 days, if tissues are preserved in refrigerated media. To accomplish this, a simple in vitro culture procedure, previously established for goat skin tissue, was utilized [28]. Using this procedure, a comprehensive in vitro study was conducted on 393 skin explants from 4 different goats. Forty explants were cultured every 10th day up to 160 days of postmortem storage. Our results show outgrowth of cells around explants in all the time points including 160 days of postmortem tissue storage in refrigerated media. To our knowledge, this is the first report of in vitro culture of mammalian cells from postmortem tissues stored in refrigerated media for such a long time of 160 days. Although, reduced temperature reduces metabolic activity and consequently the $\mathrm{pH}$ fluctuations and metabolic toxic buildup, some cells might still be active. Storing tissues in media which is buffered might help neutralize the negative effect of $\mathrm{pH}$ and toxin fluctuations and thus help the cells to survive longer in tissues. Media also contain antioxidants e.g. Vitamin- E which might help cells to counteract effects of oxidative damage, if any.

Another interesting observation of this study was that the number of outgrowing cells around explants was in decreasing order, with increased postmortem tissue storage time interval, when compared on day 10-12 of culture. This could be possible due to reduced number of viable adult skin stem cells in tissues with increasing postmortem storage time interval. In similar studies, reduction in confluence of cells with increasing postmortem time interval has been reported in goats and sheep, when tissues were stored at room temperature $[23,33]$ and in goat when stored at $4^{\circ} \mathrm{C}[20]$.

The morphology of cells derived from tissues of different storage time intervals was similar (Figure 2). However, the cell populations derived from 160-dpm tissues seem to grow slightly slow as compared to 0 -dpm and 90 -dpm cell populations (Fig. 3). Rudd et al. suggested that chromosomal imbalance may contribute to slower growth [34]. However, 160-dpm cells in this study retained normal karyotype, without any chromosomal anomalies, and thus could not be the likely cause of reduction in cell growth. Since the cells were embedded in tissues for longer time postmortem (and not involved in physiological processes at $4^{\circ} \mathrm{C}$ ), it is possible that the activity of genes involved in growth was compromised. These assumptions are supported by earlier observations by Kaji and Matsuo, where they observed reduction of growth and population doubling times of the cell populations derived from primary outgrowth that was maintained from 6-73 days after the confluence was reached [35]. All cells retained high rate of postfreezing cell-viability ensuring long term storage for conservation of precious germplasm. It was also interesting to learn that such a long postmortem time lapse of 160 days did not affect their cytogenetic stability and thus their utility for animal cloning in future.

\section{Conclusions}

This study show that, a) skin tissue of goats stored in refrigerated media can be cultured up to 160-days of postmortem storage; b) the cells are genetically stable; c) the confluence of primary outgrowing cells decreases with increasing postmortem storage time interval and; d) the cell populations derived from 0 -dpm, 90-dpm and 160-dpm tissues have comparative growth morphology but 160-dpm cells grow slightly slower. Future studies should reveal the potential of these cells for reprogramming and cloning of the animals.

\section{Acknowledgements}

Technical assistance by Xiaoling $\mathrm{Ma}$ is thankfully acknowledged. This work was partly supported by a USDA-NIFA Capacity Building Teaching Grant (No: 
Citation: Aoued HS, Singh M (2015) Recovery of Fibroblast-Like Cells after 160 Days of Postmortem Storage of Goat Skin Tissues in Refrigerated Media. J Veterinar Sci Technol 6: 236. doi:10.4172/2157-7579.1000236

2011-38821-30910) to MS. Part of this work was presented as interactive poster in SIVB meeting at Savannah, GA in June 2014. HSA is an Animal Science MS graduate student.

\section{References}

1. Loi P, Ptak G, Barboni B, Fulka J Jr, Cappai P (2001) Genetic rescue of an endangered mammal by cross-species nuclear transfer using post-mortem somatic cells. Nat Biotechnol 19: 962-4.

2. Mastromonaco GF, González-Grajales LA, Filice M, Comizzoli P (2014) Somatic cells, stem cells, and induced pluripotent stem cells: how do they now contribute to conservation? Adv Exp Med Biol 753: 385-427.

3. Lermen D, Blömeke B, Browne R, Clarke A, Dyce PW, et al. (2009) Cryobanking of viable biomaterials: implementation of new strategies for conservation purposes. Mol Ecol 18: 1030-1033.

4. Wilmut I, Schnieke AE, McWhir J, Kind AJ, Campbell KH (1997) Viable offspring derived from fetal and adult mammalian cells. Nature 385: 810-813.

5. Manthous CA (2009) Why not physician-assisted death? Crit Care Med 37 1206-1209.

6. Campbell KH, Fisher P, Chen WC, Choi I, Kelly RD, et al. (2007) Somatic cell nuclear transfer: Past, present and future perspectives. Theriogenology 68 Suppl 1: S214-231.

7. Tomii R, Kurome M, Wako N, Ochiai T, Matsunari H, et al. (2009) Production of cloned pigs by nuclear transfer of preadipocytes following cell cycle synchronization by differentiation induction. J Reprod Dev 55: 121-127.

8. Blelloch RH, Hochedlinger K, Yamada Y, Brennan C, Kim M, et al. (2004) Nuclear cloning of embryonal carcinoma cells. Proc Natl Acad Sci U S A 101 13985-13990.

9. Oback B, Wells DN (2007) Cloning cattle: the methods in the madness. Adv Exp Med Biol 591: 30-57.

10. Mastromonaco GF, Perrault SD, Betts DH, King WA (2006) Role of chromosome stability and telomere length in the production of viable cell lines for somatic cell nuclear transfer. BMC Dev Biol 6: 41

11. Ogura A, Inoue K, Wakayama T (2013) Recent advancements in cloning by somatic cell nuclear transfer. Philos Trans R Soc Lond B Biol Sci 368 20110329.

12. Hoshino Y, Hayashi N, Taniguchi S, Kobayashi N, Sakai K, et al. (2009) Resurrection of a bull by cloning from organs frozen without cryoprotectant in a -80 degrees $c$ freezer for a decade. PLoS One 4: e4142.

13. Palmer TD, Schwartz PH, Taupin P, Kaspar B, Stein SA, et al. (2001) Cell culture. Progenitor cells from human brain after death. Nature 411: 42-43.

14. Viel JJ, McManus DQ, Cady C, Evans MS, Brewer GJ (2001) Temperature and time interval for culture of postmortem neurons from adult rat cortex. J Neurosci Res 64: 311-321.

15. Wakayama S, Ohta H, Hikichi T, Mizutani E, Iwaki T, et al. (2008) Production of healthy cloned mice from bodies frozen at -20 degrees $C$ for 16 years. Proc Natl Acad Sci U S A 105: 17318-17322.

16. Erker L, Azuma H, Lee AY, Guo C, Orloff S, et al. (2010) Therapeutic liver reconstitution with murine cells isolated long after death. Gastroenterology 139 1019-1029.

17. May SR, Wainwright JF (1985) Integrated study of the structural and metabolic degeneration of skin during 4 degrees $C$ storage in nutrient medium. Cryobiology 22: 18-34

18. Silvestre MA, Saeed AM, Cervera RP, Escribá MJ, García-Ximénez F (2003) Rabbit and pig ear skin sample cryobanking: effects of storage time and temperature of the whole ear extirpated immediately after death. Theriogenology 59: 1469-1477.

19. Silvestre MA, Sánchez JP, Gómez EA (2004) Vitrification of goat, sheep, and cattle skin samples from whole ear extirpated after death and maintained at different storage times and temperatures. Cryobiology 49: 221-229.

20. Okonkwo C, Singh M (2015) Recovery of fibroblast-like cells from refrigerated goat skin up to $41 \mathrm{~d}$ of animal death. In Vitro Cell Dev Biol Anim 51: 463-469.

21. Nahm WK, Zhou L, Falanga V (2002) Sustained ability for fibroblast outgrowth from stored neonatal foreskin: a model for studying mechanisms of fibroblast outgrowth. J Dermatol Sci 28: 152-158.

22. Latil M, Rocheteau P, Châtre L, Sanulli S, Mémet S, et al. (2012) Skeleta muscle stem cells adopt a dormant cell state post mortem and retain regenerative capacity. Nat Commun 3: 903.

23. Singh M, Ma X (2014) In Vitro Culture of Fibroblast-Like Cells From Sheep Ear Skin Stored at $25-26^{\circ} \mathrm{C}$ for 10 Days After Animal Death International. Journal of Biology 6: 96- 102

24. Strober W (2001) Trypan blue exclusion test of cell viability. Curr Protoc Immunol Appendix 3: Appendix 3B.

25. Singh M, Ma X, Amoah E, Kannan G (2011) In vitro culture of fibroblast-like cells from postmortem skin of Katahdin sheep stored at $4{ }^{\circ} \mathrm{C}$ for different time intervals. In Vitro Cell Dev Biol Anim 47: 290-293.

26. Meisner LF, Johnson JA (2008) Protocols for cytogenetic studies of human embryonic stem cells. Methods 45: 133-141.

27. SJ O'Brien, JC Menninger, WG Nash (2006) Atlas of Mammalian Chromosomes John Wiley and Sons, NJ.

28. Singh M, Sharma AK (2011) Outgrowth of fibroblast cells from goat skin explants in three different culture media and the establishment of cell lines. In Vitro Cell Dev Biol Anim 47: 83-88.

29. Li XC, Yue H, Li CY, He XH, Zhao QJ, et al. (2009) Establishment and characterization of a fibroblast cell line derived from Jining Black Grey goat for genetic conservation. Small Ruminant Res. 87: 17-26.

30. Jaszczak K, Członkowska M, Guszkiewicz A, Parada R (1991) Cytogenetic analysis of experimental interspecies goat-sheep chimera. J Hered 82: 244

31. Jaszczak K, Parada R, Guszkiewicz A (1999) Cytogenetic study of some tissues and age-related changes in cell proportions in a goat-sheep chimera. Cytogenet Cell Genet 84: 55-57.

32. Singh M, Sharma C, Yadav P (2011) Characterization of GSF289: a fibroblas cell line derived from goat ear skin explants. J Biotech Res 3: 1-6.

33. Singh M, Ma X, Sharma A (2012) Effect of postmortem time interval on in vitro culture potential of goat skin tissues stored at room temperature. In Vitro Cell Dev Biol Anim 48: 478-482.

34. Rudd NL, Hoar DI, Williams SE, Hennig UG (1989) Genotype and the cryopreservation process affect the levels of aneuploidy and chromosome breakage in cultured human fibroblasts. Genome 32: 196-202.

35. Kaji K, Matsuo M (1980) Aging of chick embryo fibroblasts in vitro-IV. Doubling potential and metabolic time. Exp Gerontol 15: 481-5. 